\title{
Os alunos vêm cada vez mais mal preparados...
}

“..tenho encontrado bastantes dificuldades provenientes da má preparação dos meus alunos. Os exames na nossa instrução secundária são sempre muito fáceis; facilitamos mesmo na maior parte do grande número dos nossos liceus de província. E pelo que respeita aos exames de Princípios de Física e Química e História Natural, é preciso que o professor dos cursos superiores não conte absolutamente nada com os conhecimentos que os seus discípulos deveriam ter das matérias dos respectivos programas. O ensino não tem a feição experimental que deveria ter; os estudantes aprendem de cor os seus compêndios, e passado pouco tempo têm esquecido tudo. Isto é ainda mais verdade da química liceal. Tem-me sucedido muitas vezes falar nas minhas explicações de fenó- menos vulgares observados em corpos vulgares, e reconheci que a maioria dos meus discípulos os ignoram. Quando sabem que existe o amoníaco e o ácido clorídrico, é vulgar que ignorem que se trata de dois corpos gasosos muito solúveis em água.

Desta falta de conhecimentos preparatórios é que resultam as dificuldades que eu tenho encontrado na exposição da química filosófica, e que igualmente creio têm encontrado outros professores de química em escolas superiores. Há de certo excepções; há alguns bons professores de introdução nos liceus; há alguns estudantes que mesmo com maus professores se apresentam regularmente preparados, mas são excepções muito honrosas que mais servem para confirmar a regra geral." 